\title{
Preliminary Phytotoxicity Test on Salinity Against Mangrove Plants of Rhizophora mucronata
}

\author{
Harmin Sulistiyaning Titah ${ }^{1 *}$, Ipung Fitri Purwanti ${ }^{1}$, Herman Pratikno ${ }^{2}$, \\ Rachmi Layina Chimayati ${ }^{1}$, Handayanu ${ }^{2}$
}

1 Department of Environmental Engineering, Faculty of Civil, Environmental and Geoscience Engineering, Institut Teknologi Sepuluh Nopember, Keputih, Sukolilo, 60111 Surabaya, Indonesia

2 Department of Ocean Engineering, Faculty of Marine Technology, Institut Teknologi Sepuluh Nopember, Keputih, Sukolilo, 60111 Surabaya, Indonesia

* Corresponding author's e-mail: harminsulis@gmail.com, harmin_st@its.ac.id

\begin{abstract}
The phytotechnology concept that is applied for a bio-desalination reactor become a new desalination technology. The desalination technology can be called as bio-desalination technology to remove ions of $\mathrm{Na}^{+}$and $\mathrm{Cl}^{-}$in brackish or saline water using mangrove plant. Before the mangrove plants were used in bio-desalination technology, the preliminary phytotoxicity test was conducted. The purpose was to determine the salinity concentration at which the mangrove species of Rhizophora mucronata can survive. The preliminary phytotoxicty test was carried out using a plastic reactor that was designed as a reed bed system. The reactors filled with gravel, sand, and artificial saline water. The variation of the $\mathrm{NaCl}$ concentrations were $0 \mathrm{mg} / \mathrm{L}$ as control, 10,000; 20,000; 30,000; 40,000, and $50,000 \mathrm{mg} / \mathrm{L}$. The physical observation of the survival condition of Rhizophora mucronata was carried out during the preliminary test for 7 days. The analysis of Scanning Electron Microscopy (SEM) on Rhizophora mucronata was conducted at the end of exposure. The results showed that Rhizophora mucronata could not survive at the concentrations of 40,000 and 50,000 mg/L. Rhizophora mucronata changed the color of the leaves to brown and the stems become softer. Multiple cell damage and the decreasing trend of sodium and chloride amounts occured on roots and stems at the salinity concentration of 50,000 $\mathrm{mg} / \mathrm{L}$. In conclusion, the high of salinity concentration (>30,000 mg/L) can be toxic to Rhizophora mucronata.
\end{abstract}

Keywords: Bio-desalination, brackish water, mangrove, salinity, preliminary phytotoxicity

\section{INTRODUCTION}

In general, bio-desalination technology is a technology that utilizes bacteria to remove $\mathrm{Na}^{+}$ ions and $\mathrm{Cl}^{-}$ions in seawater. The application of phytotechnology concept for bio-desalination reactor is a new technology. The mangrove plants were chosen to be used in bio-desalination. Mangroves plants are the characteristic littoral plant formation of tropical and subtropical sheltered coastlines (FAO, 1994). According to Pal et al. (2017), mangrove plants are on the land sea interface, they are always associated with and subjected to saline seawater. Before the mangrove plant were used in bio-desalination technology, it should be tested first to know the tolerance of the plant to the $\mathrm{NaCl}$ exposure in the preliminary phytotoxicity test. A phytotoxicity bioassay was used to select plant species in phytoremediation that were able to reduce the organic or inorganic pollutant in a contaminated site. The bioassay can potentially reduce the number or pot or greenhouse degradation studies that need to be conducted before plant species can be chosen for phytoremediation (Kirk et al., 2002). In this step, the preliminary screening is conducted to find the tolerance of plant species to an organic or inorganic pollutant. Phytotoxicity is a term used to describe the toxic effect of a compound on plant growth. Such damage may be caused by a wide 
variety of compounds, such as heavy metals. The toxicity result when the plant is incapable of sequestering or removing excess concentrations of organic or inorganic polutant. Plants have evolved mechanisms to deliberately exclude, excrete or biologically transform these metals into less toxic forms (Duxbury, 2000).

Mangrove plants belong to the plants that can survive at saline environment. Saline condition is not a prerequisite for their development, rather mangroves choose saline condition to avoid the competition with the more vigorous terrestrial plants (Pal et al., 2017). Mangroves are not halophiles, rather salt tolerant plants based on the physiological studies. However, the excessive saline conditions retard seed germination, impede growth and development of mangroves. According to Scholander et al. (1962) in Suarez and Medina (2008), some of mangrove can be tolerant to salinity because it can be an be released through a specific gland on the leaves. This mangrove that has salt gland was called secreter, i.e Avicennia spp., Aegiceras spp., dan Aegialitis spp.

The research was conducted as the first step to use Rhizophora mucronata in bio-desalinasion reactor using reed bed system. The purpose of this research was to determine the maximum concentration of $\mathrm{NaCl}$ to survive of $R h i$ zophora mucronata. The results will be used for further investigation.

\section{MATERIALS AND METHODS}

\section{Preparation of mangrove}

Rhizophora mucronata were collected from nursery of mangrove at Wonorejo, Surabaya. The age of plants were about 3 months. The mangove species that was used in this research was Rhizophora mucronata. The reasons to use Rhizophora mucronata were based on Saeni and Tanasale (1999), Rhizophora apiculata, Rhizophora mucronata, and Xylocarpus granatum can reduce concentration of salt in water. According to Khan and Aziz (2001), the relative salt tolerance is exhibited by Avicennia marina, Ceriops tagal and Rhizophora mucronata species. Our previous study showed that Avicennia marina can survive up to $30.000 \mathrm{mg} / \mathrm{L}$ of $\mathrm{NaCl}$. After that Rhizophora mucronata were placed in a green house for 1 week to conduct aclimatization.

\section{Preliminary phytotoxicity test}

The preiminary phytotoxicity experiment was conducted based on the Organization for Economic Co-operation and Development (OECD) 208 (1984) and ISO 11269-2 (1995). A preliminary phytotoxicity test was conducted using a plastic reactor with the diameter of $28 \mathrm{~cm}$ and height of $32 \mathrm{~cm}$. There were 2 layer of media. A layer of medium gravel $(\Phi$ in $20 \mathrm{~mm}$ ) was placed at the bottom of the reactor with $5 \mathrm{~cm}$ of the depth, and another layer of sand was placed at the top with depth of $10 \mathrm{~cm}$. After gravel and sand layers, the artificial of saline water was filled with high of $5 \mathrm{~cm}$. Figure 1 shows the design of reactor and Figure 2 depicts the running of preliminary phytotoxicity test. The preliminary phytotoxicity test was conducted for 7 days. Number of Rhizophora mucronata was 3 plants in 1 reactor. The range of $\mathrm{NaCl}$ concentrations was: $0 \mathrm{mg} / \mathrm{L}$ as control, 10,$000 ; 20,000 ; 30,000 ; 40,000$, and $50,000 \mathrm{mg} / \mathrm{L}$. The range of these concentrations was chosen due to all those salinity concentrations showed the low to high salinity. The solution of $\mathrm{NaCl}$ was prepared from $\mathrm{NaCl}$ pro analysis powder (Merck, USA). The nutrient addition was not carried out during the perliminary phytotoxicity test due to the applications of nutrient fertilizers that can alleviate the process of phytotoxicity (Cheng et al., 2012). The physical observation on Rhizophora mucronata was carried during the preliminary phytotoxicity test.

\section{Fresh and dry weight determination}

Determination of plants fresh weight $(\mathrm{FW})$ and plants dry weight (DW) were carried out at the end of the preliminary phytotoxicity test. The growth of Rhizophora mucronata was monitored by determining its wet weight measured immediately after harvest at the end of the test. Rhizophora mucronata were separated into roots, stems, leaves. The roots of Rhizophora mucronata were washed to remove any sand and blotted gently with soft paper towel to remove any free surface moisture. All plants parts were dried in an oven Memmert (Germany) at $105^{\circ} \mathrm{C}$ for $24 \mathrm{~h}$ for dry weight measurement (Mieszkalska and Lukaszewska, 2011).

\section{Analysis of scanning electron microscopy}

The purpose of scanning electron microscopy (SEM) analysis was to find the impact of $\mathrm{NaCl}$ on 


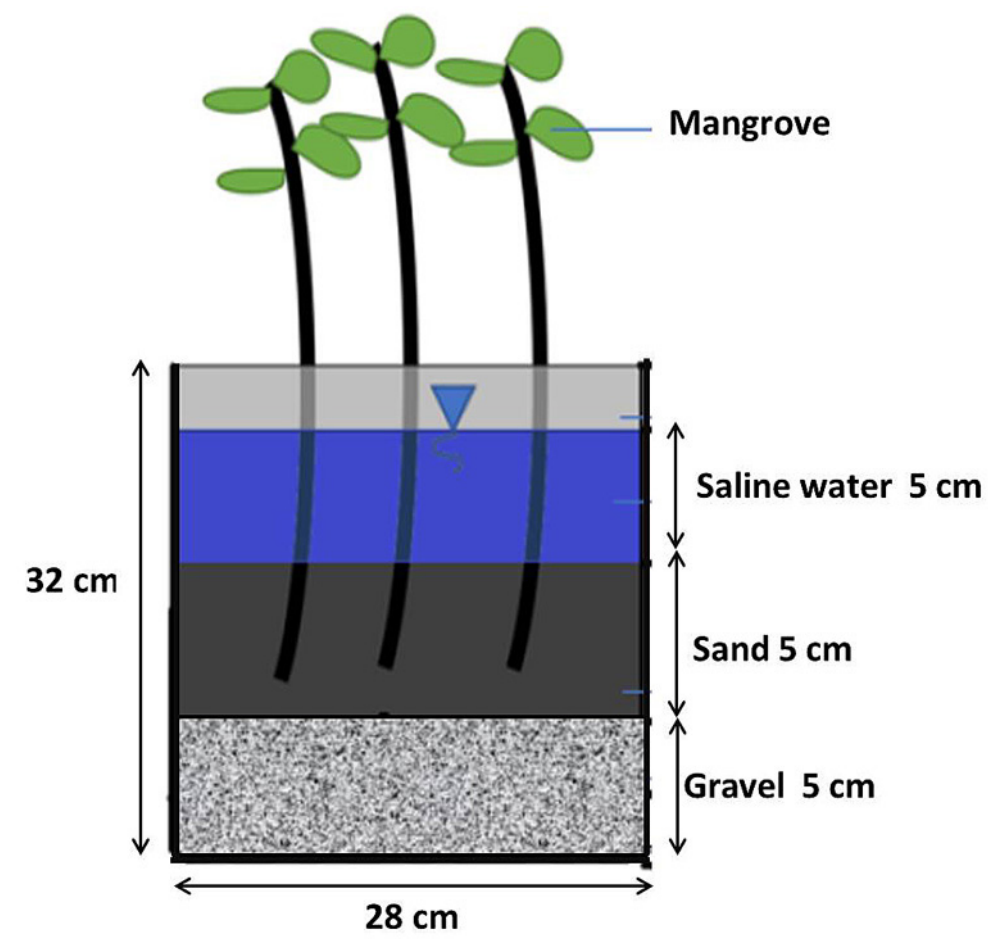

Figure 1. Design of reactor

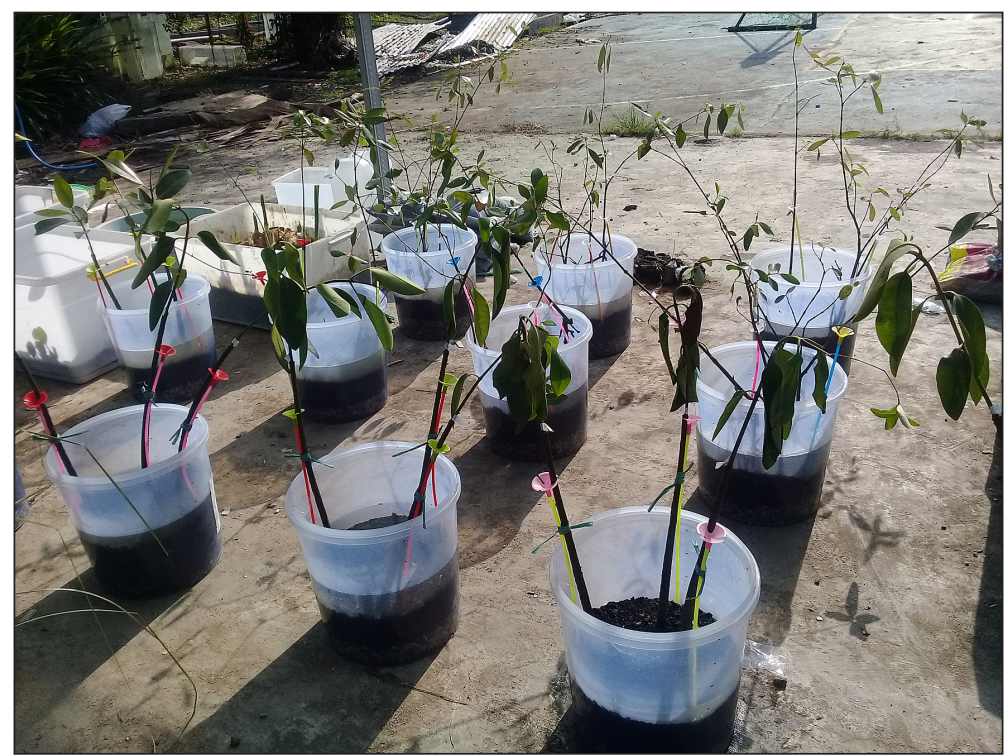

Figure 2. The running of preliminary phytotoxicity test

tissues of roots, stems and leaves of Rhizophora mucronata. Scanning electron microscopy (SEM) analysis was conducted using SEM (Zeiss Model EVO MA10, Germany) at Laboratory of Energi, LPPM - ITS. The analysis of unsure in Rhizophora mucronata using scanning electron microscopy-energy dispersive X-ray (SEM-EDX) and mapping of unsure was conducted after 7 days of exposure at control and the higher concentration of salinity. The sample preparation was carried out using a method from Pathan et al. (2008). After driying, all samples were cut into small pieces and coated with metal, $\mathrm{Au}$ (gold), using a coating machine (Emitec, Germany). 


\section{RESULTS AND DISCUSSION}

\section{Observation of physical on survival Rhizophora mucronata}

All Rhizophora mucronata were in good condition at day 0 until day 2 . The wilting of leaves began at Day 3 in the $\mathrm{NaCl}$ concentration of 40,000 and $50,000 \mathrm{mg} / \mathrm{L}$. According to Titah et al. (2013a), the wilting, especially of the leaves, was observed as an initial symptom of phytotoxicity. However, the wilting leaves also occured at control and all salinity concentration at the end day of exposure (Day 7). Rhizophora mucronata changed the color of the leaves to brown; wilting of leaves, decreasing of number of leaves, softening of stems occurred at concentrations of 40,000 and $50,000 \mathrm{mg} / \mathrm{L}$ for Day 7 of exposure.

Figure 3 depicts the condition of the whole Rhizophora mucronata plant after the end of preliminary phytotoxicity test. On the basis of the picture in table, roots of Rhizophora mucronata can grow well at control and the salinity of concentration up to $30,000 \mathrm{mg} / \mathrm{L}$. However, the size of Rhizophora mucronata roots was smaller at the concentration of 40,000 and $50,000 \mathrm{mg} / \mathrm{L}$ compared with control and other concentrations. The stems became softer than control and other concentrations. The yellowing and wilting of leaves were greater than control and other concentrations. It showed that Rhizophora mucronata could not survive at the concentrations of 40,000 and $50,000 \mathrm{mg} / \mathrm{L}$. The high salinity can cause osmotic stress and reduce the availability of water, resulting in stomatal closure and reduced supply of carbon dioxide (Tanaka et al., 1999; Li et al., 2008). According to Medina and Francisco
(1997), the significant decreases in leaf number and area of Avicennia. germinans during increasing of soil salinity. The accelerated leaf mortality rates of mangrove were often accompanied by decreases in leaf production rates, finally leading to the deaths of plants under extreme salinity stress (Ball and Pidsley, 1995).

\section{Fresh and dry weight of Rhizophora mucronata}

Figure 4 depicts the fresh-dry weight biomass of Rhizophora mucronata during the preliminary phytotoxicity test. The weight of dry biomass in roots, stems and leaves decreased similarly with the fresh weight. The FW and DW of roots, stems and leaves at control were $37.1 ; 22.4 ; 88.3 ; 82.9$; 11.1 and $6.4 \mathrm{~g}$, respectively. The decreasing of FW and DW on stems of Rhizophora mucronata showed less reduction at control.

Figure 5 shows the decreasing precentage of whole Rhizophora mucronata weight during the preliminary phytotoxicity test. It was observed that the slightly decreasing occured at $10,000 \mathrm{mg} / \mathrm{L}(9.1 \%)$ compared with control (18.2\%). According to Titah et al. (2013a), the decreasing of plant biomass in control after the end of exposure could be due to the decreasing nutrient since no additional nutrient was added. The nutrients were available in sand, but the concentration of those nutrients was limited. The sand contents of the macronutrients were $29.2 \mathrm{mg} / \mathrm{kg} \mathrm{N}$ (nitrate), $1.2 \mathrm{mg} / \mathrm{kg} \mathrm{K}, 13.0 \mathrm{mg} / \mathrm{kg} \mathrm{SO}_{4}{ }^{2-}, 86.5 \mathrm{mg} / \mathrm{kg} \mathrm{Ca}$, $7.4 \mathrm{mg} / \mathrm{kg} \mathrm{Mg}$ whereas the micronutrient contents were $6.4 \mathrm{mg} / \mathrm{kg} \mathrm{Cl}, 5.5 \mathrm{mg} / \mathrm{kg}^{1} \mathrm{Fe}, 0.04 \mathrm{mg} / \mathrm{kg}$ $\mathrm{Zn}$ and $1.62 \mathrm{mg} / \mathrm{kg} \mathrm{Mn}$, and the trace elements were not detected by Titah et al. (2013b).

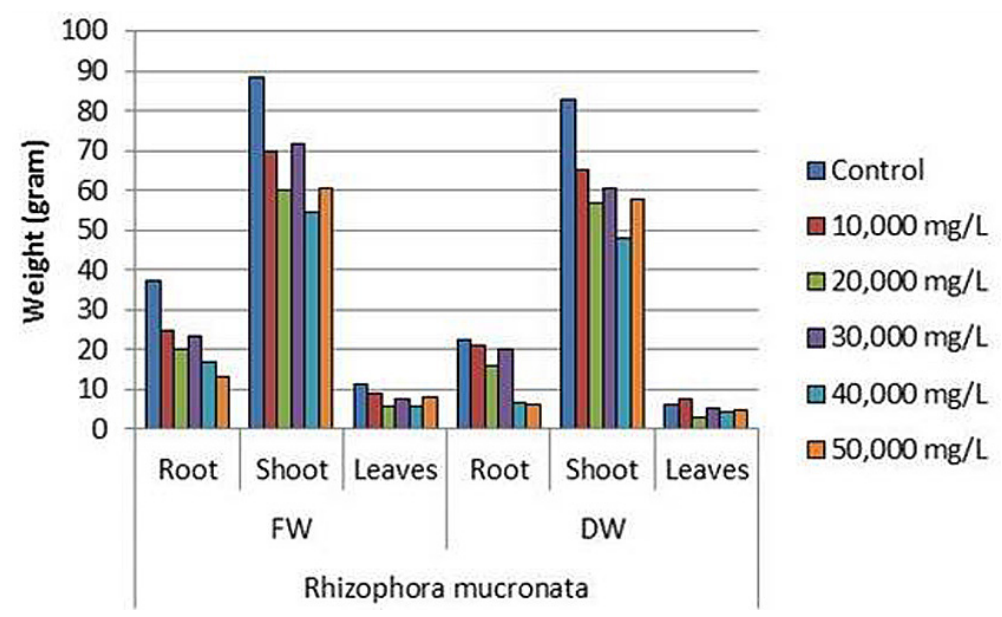

Figure 4. FW and DW of part of Rhizophora mucronata at the end of preliminary phytotoxicity test 


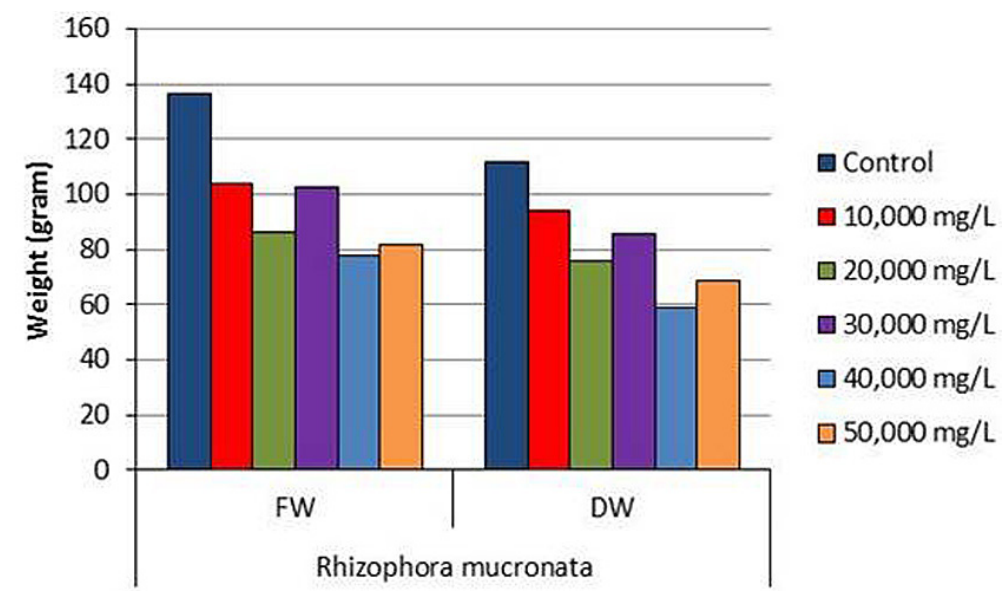

Figure 5. FW and DW of whole Avicennia marina at the end of preliminary phytotoxicity test

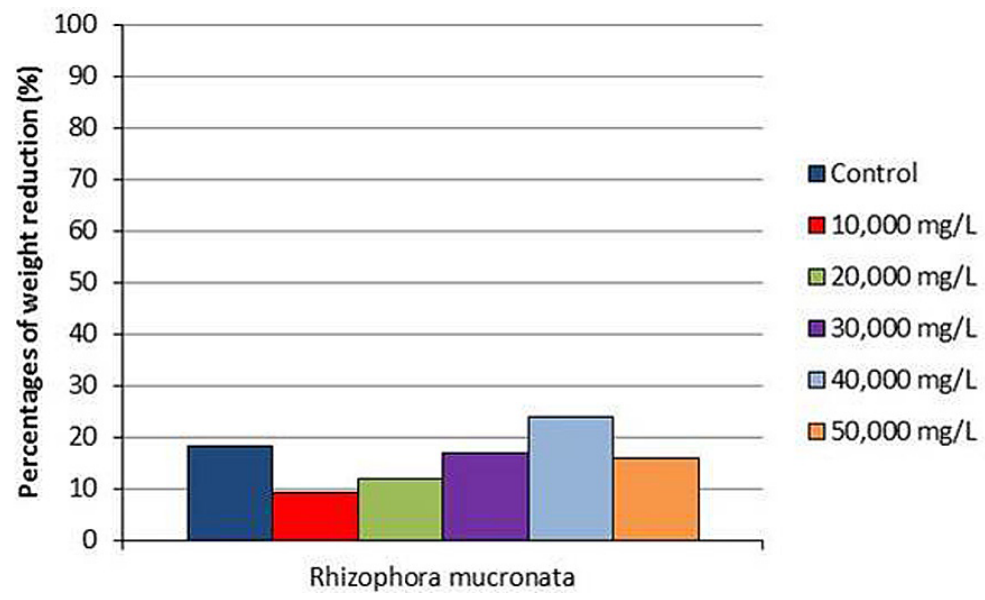

Figure 6. The reduction precentage of whole Rhizophora mucronata weight during the preliminary phytotoxicity test

The decreasing precentage of whole $R h i-$ zophora mucronata weight at all salinity concentrations were $9.3,11.9,16.8,23.9$ and $15.9 \%$ at the $\mathrm{NaCl}$ concentration of 10,$000 ; 20,000$; 30,$000 ; 40,000$; and $50,000 \mathrm{mg} / \mathrm{L}$, respectively. The highest decreasing precentage occured at at $\mathrm{NaCl}$ concentration of $40,000 \mathrm{mg} / \mathrm{L}$. According to Rattanawat et al. (2011), the nominal change in dry biomass production indicated severe phytotoxicity of polutants in the contaminated environment. According to Saeni and Tanasale (1999), salinity treatment on mangrove can affect the DW of mangrove. According to Khan and Aziz (2001), the mangrove biomass declined with a further increase in salinity. The growth of mangrove declined with an increase in salinity (Ball, 1988). High media salinity affects the plant growth due to low water potentials, ion toxicities, nutrient deficiencies or a combination of all these factors (Khan et al., 2000). Growth and survival of halophytes are dependent on the high levels of ion accumulation in their tissue for the maintenance of turgor and osmotic adjustment (Flowers et al., 1977).

The cumulative effects such as withering, driying, and death of the plant as response versus salinity concentration are drawn using computer program, it was called the concentration-effects curve (Landis and Yu, 1995). The salinity concentration that results in $50 \%$ of the measurement effects can be plotted on the graph. Figure 7 showed the curve of the concentration - effects on Rhizophora mucronata at variable of salinity concentration. The $\mathrm{EC}_{50}$ value for single salinity phytotoxicity to Rhizophora mucronata was predicted between 30,000 and 40,000 mg/L. According to Khan and Aziz (2001), Avicennia marina, Ceriops tagal and Rhizophora mucronata showed optimal growth at $22,000 \mathrm{mg} / \mathrm{L}$ of salinity concentration. According to Chen and Ye (2014), old seedlings of mangrove species of Excoecaria agallocha grew best at the salinities below $5 \mathrm{ppt}$ 


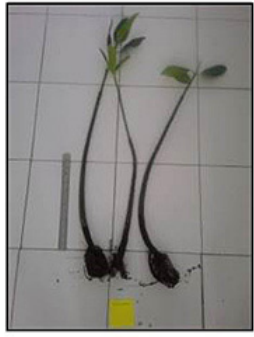

(a)

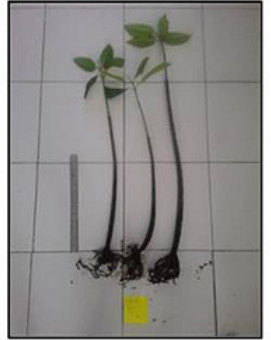

(b)

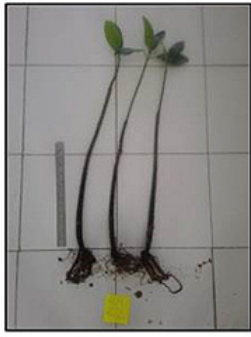

(c)

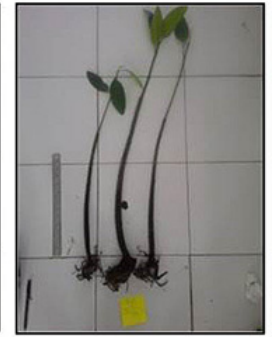

(d)

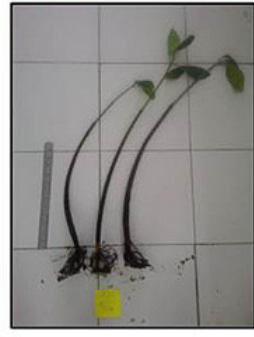

(e)

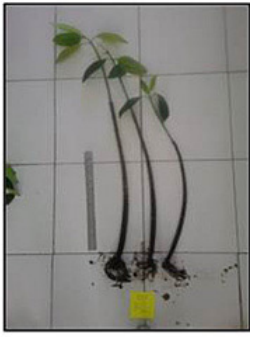

(f)

Figure 3. Summary physical condition of whole plants of Rhizophora mucronata for 7 days of exposure at (a) control (b) 10,000 (c) 20,000 (d) 30,000 (e) 40,000 (f) 50,000 mg/L

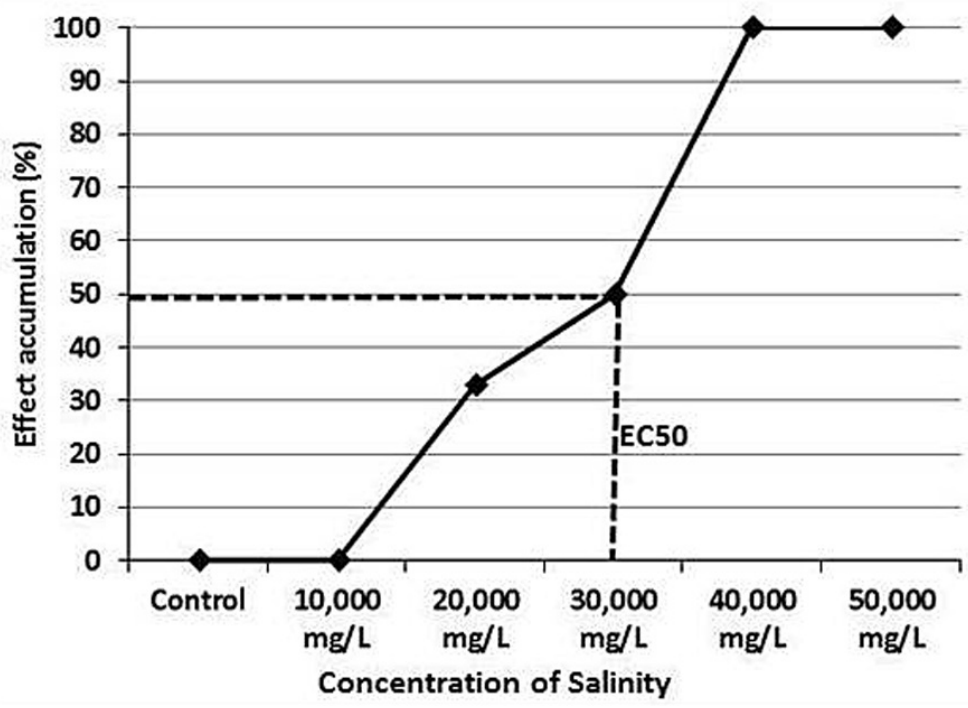

Figure 7. The concentration - effects curve on Rhizophora mucronata at variable salinity concentration

and they survived the whole cultivation at $25 \mathrm{ppt}$ or $25,000 \mathrm{mg} / \mathrm{L}$. However, mangroves could accumulate inorganic ions or compatible solutes like betaine, proline, or sugar alcohol as osmotica to counter the toxic effects of salinity when mangrove grew in salt stressed habitat (Ye et al., 2005).

\section{RESULTS OF SEM}

Figure 8 depicts the SEM results of Rhizophora mucronata. On the basis of the Figure $8 \mathrm{a}$ and $8 \mathrm{~d}$ with $51 \mathrm{X}$ of magnification, the cell of root at control showed no damage, but the cell of the root at salinity concentration of $50,000 \mathrm{mg} / \mathrm{L}$ showed many damage. This similar condition was shown on stem of salinity concentration of $50,000 \mathrm{mg} / \mathrm{L}$ (Figure $8 \mathrm{~b}$ and $8 \mathrm{~d}$ ) with the magnification of $1,000 \mathrm{X}$. However, SEM on leaves did not show the difference (Figure $8 \mathrm{~b}$ and $8 \mathrm{~d}$ ) with 2,000 X magnification. On the basis of the results of SEM on leaves, stomatal closure was similar at control and salinity concentration of $50,000 \mathrm{mg} / \mathrm{L}$. Although, stomatal closure at high salinities minimizes water loss through transpiration, which is however, accompanied by reduced carbon gain, leading to the suppression of photosynthesis (Nandy et al., 2007).

Figure 9 depicted the summary of EDX on roots, stems and leaves of Rhizophora mucronata at control and concentration salinity of $50,000 \mathrm{mg} / \mathrm{L}$. The sodium and chloride were observed on roots, stems and leaves of Rhizophora mucronata at control. The sodium weight concentration at control were 2.36; 0.57 and $1.78(\%)$ in root, shoot and leaves, respectively. The chloride weight at control were $3.35 ; 1.13$ and $1.88(\%)$ in root, shoot and leaves, respectively. The chloride amounts at salinity concentration of $50,000 \mathrm{mg} / \mathrm{L}$ were $1.05 ; 1.03$ and $1.41(\%)$ in root, shoot and leaves, respectively. The sodium amounts at the salinity concentration of $50,000 \mathrm{mg} / \mathrm{L}$ were 0.68 ; 0.48 and $0.82(\%)$ in root, shoot and leaves, respectively. Rhizophora mucronata can take 


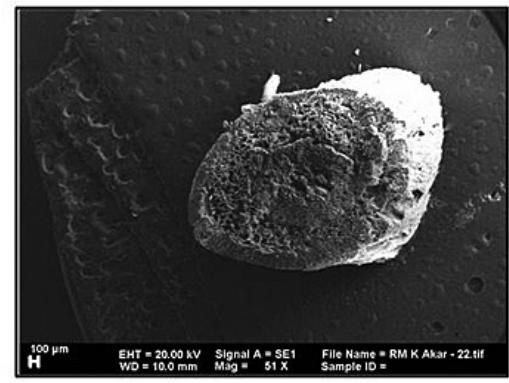

(a)

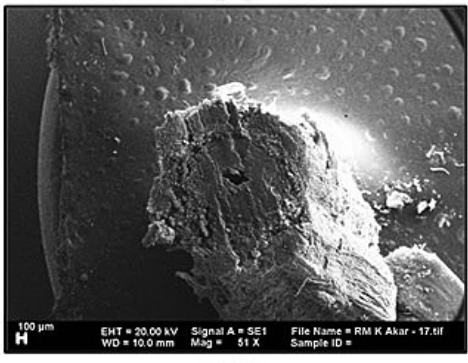

(d)

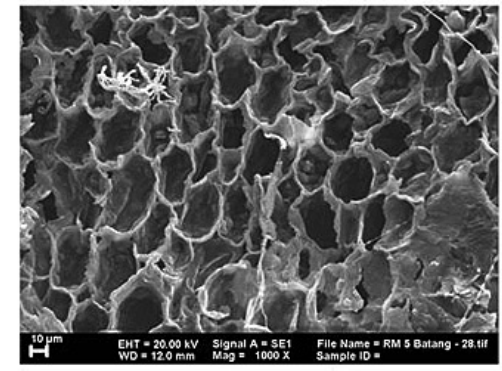

(b)

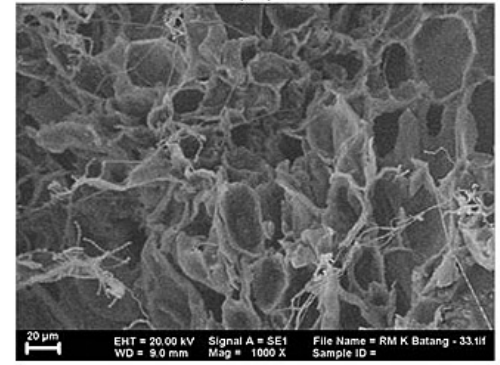

(e)

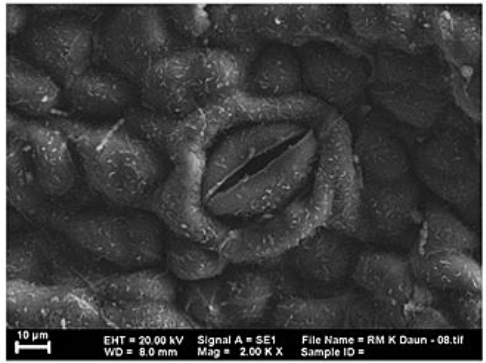

(c)

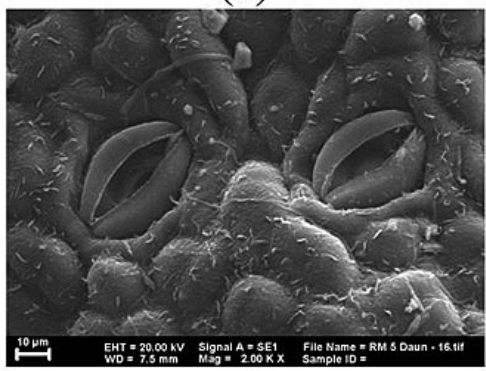

(f)

Figure 8. SEM results of Rhizophora mucronata at the end of preliminary phytotoxicity test (a) root (b) stem (c) leaves at control, (d) root (e) stem (f) leaves at salinity concentration of 50,000 mg/L

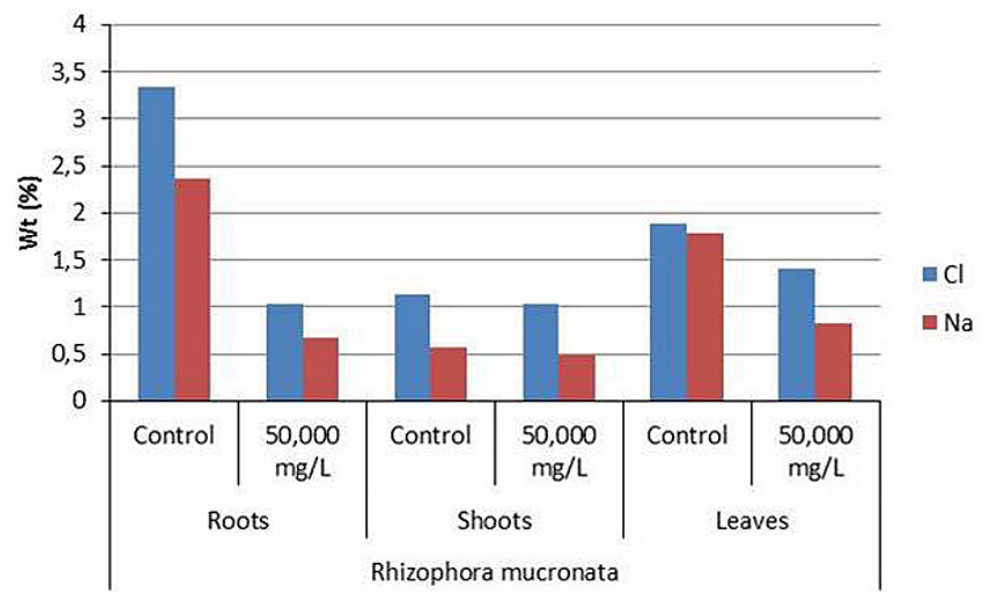

Figure 9. EDX results on roots, stems and leaves of Rhizophora mucronata at the end of preliminary phytotoxicity test at control and salinity concentration of $50,000 \mathrm{mg} / \mathrm{L}$.

up sodium and chloride, and then, sodium and chloride are translocated to aerial part, stems and leaves, of the mangrove. According to Popp (1994), mangroves accumulate high concentrations of inorganic ions like most other salt-tolerant plants that function in the osmoregulation of leaves and other tissues. Avicennia marina accumulated the highest concentrations of ions followed by Rhizophora mucronata (Khan and Aziz, 2001), it meaning that the ability of Rhizophora mucronata to accumulate inorganic ions was lower compared with Avicennia marina. Our previous study also showed that Avicennia marina can accumulate high of sodium and chloride at their tissue. Avicennia marina has the ability to regulate salt content by secreting it through the glands (Hegemayer, 1997). Rhizophora mucronata have the ability to exclude salts via root ultrafiltration but do not have the ability to secrete salt through leaves (Hegemayer, 1997). The mangrove can decrease salinity, chiorinity, and conductivity of water, except for water which did not contain sea water. The increasing of chloride ion in the tissues was influenced by the increase of chloride ion in root tissues (Saeni and Tanasale 1999). However, the condition for Rhizophora mucronata did not occur at the salinity concentration of $50,000 \mathrm{mg} / \mathrm{L}$. The decreasing trend of 
sodium and chloride amounts occured on roots, stems and leaves of Rhizophora mucronata at the salinity concentration of $50,000 \mathrm{mg} / \mathrm{L}$.

\section{CONCLUSIONS}

On the basis of the physical observation during the prelimary phytotoxicity test for 1 week, Rhizophora mucronata could not survive at the concentrations of 40,000 and 50,000 mg/L. Rhizophora mucronata changed the color of the leaves to brown, the stems become softer and declined of FW-DW. Rhizophora mucronata can survive up to $30,000 \mathrm{mg} / \mathrm{L}$ although the wilting leaves occured at this concentration. The results of SEM showed extensive cell damage and the decreasing trend of sodium and chloride amounts occured on roots and stems at the salinity concentration of $50,000 \mathrm{mg} / \mathrm{L}$. In conclusion, the high concentration of salinity can be toxic to Rhizophora mucronata.

\section{Acknowledgements}

The author would like to thank KemenristekDIKTI through scheme of Penelitian Dasar Unggulan Perguruan Tinggi - PDUPT 2018 No. 887/PKS/ITS/2018 and No. 128/SP2H/PTHBN/ $\mathrm{DRPM} / 2018$ for funding this research.

\section{REFERENCES}

1. FAO. 1994. Mangrove forest management guidelines. FAO Forestry paper, Rome 117.

2. Pal, N., Sufia, Z., Prosenjit, P., Abhijit, M. 2017. Impact of Aquatic Salinity on Mangrove Seedlings: A Case Study on Heritiera fomes (Common Name: Sundari). Biomedical Journal of Scientific \& Technical Research (BJSTR), 1(4). DOI: 10.26717/BJSTR.2017.01.000348.

3. Kirk, J.L, Klirnomos, J.N., Lee, H., and Trevors, J.T. 2002. Phytotoxicity Assay to Assess Plant Species for Phytoremediation of Petroleum-Contaminated Soil. Bioremediation Journal, 6, 57-63.

4. Duxbury, P. H. 2000. Phytoremediation Systems for Treatment of Contaminant Mixtures in Soil. Thesis Master of Science. Department of Agriculture and Biosystems Engineering. Macdonald Campus, McGill University.

5. Scholander, P. F., Hammel, H.T., Hemmimgsen, E.A. and Garey, W. 1962. Salt balance in mangrove. Plant Physiology, 37, 722-729.
6. Suárez, N. and Medina, E. 2008. Salinity effects on leaf ion composition and salt secretion rate in Avicennia germinans (L.) L. Brazilian Journal of Plant Physiology, 20(2), 131-140.

7. Saeni, M.S., and Tanasale, F.J.D.P.. 1999. Desalinasi air laut dengan tanaman mangrove (Desalination of Sea Water by Mangrove) Project Mangrove.

8. Khan, M. A., Irfan Aziz, I. 2001. Salinity tolerance in some mangrove species from Pakistan Wetlands Ecology and Management, 9, 219-223.

9. OECD, Organization for economic co-operation and development. 1984.Guidelines for testing of chemicals 208, Terrestrial Plants, Growth Test.

10. ISO 11269-2. 1995. Soil quality-determination of the effects of pollutants on soil flora-effects of chemicals on the emergence and growth of higher plants.

11. Cheng, H., Wang, Y.S., Ye, Z.H., Chen, D.T., Wang, Y.T. 2012. Influence of $\mathrm{N}$ deficiency and salinity on metal $(\mathrm{Pb}, \mathrm{Zn}$ and $\mathrm{Cu})$ accumulation and tolerance by Rhizophora stylosa in relation to root anatomy and permeability. Environmental Pollution, 164, 110-117.

12. Mieszkalska, K., Làukaszewska, A. 2011. Effect of the silicon and phosphoruscontaining fertilizer on geranium (Pelargonium hortorum L.H. Bailey) response to water stress. Acta Scientiarum Polonorum-Hortorum Cultus , 10(3), 113-121.

13. Pathan, A.K., Bond, J., and Gaskin R.E. 2008. Sample preparation for scanning electron microscopy of plant surfaces-Horses for courses. Micron, 39(8),1049-1061.

14. Titah, H. S., Abdullah, S. R. S., Idris, M., Anuar, N., Basri, H. and Mukhlisin, M. 2013a. Arsenic toxicity on Ludwigia octovalvis in spiked sand. Bulletin of Environmental Contamination and Toxicology, 90(6), 714-719.

15. Tanaka, Y., Hibino, T., Hayashi, Y., Tanaka, A., Kishitani, S. 1999. Salt tolerance of transgenic rice over-expressing yeast mitochondrial Mn-SOD in chloroplasts. Plant Science, 148, 131-138.

16. Li, N., Chen, S.L., Zhou, X.Y., Li, C.Y., Shao, J. 2008. Effect of $\mathrm{NaCl}$ on photosynthesis, salt accumulation and ion compartmentation in two mangrove species, Kandelia candel and Bruguiera gymnorrhiza. Aquatic Botany, 88, 303-310.

17. Medina, E., Francisco, M. 1997. Osmolality and d13C of leaf tissue of mangrove species from environments of contrasting rainfall and salinity. Estuarine, Coastal and Shelf Science, 45, 337-344.

18. Ball, M.C., Pidsley, S.M. 1995. Growth responses to salinity in relation to distribution of two mangrove species, Sonneratia alba and S. lanceolata, in northern Australia. Functional Ecology, 9, 77-85.

19. Titah, H. S., Abdullah, S. R. S., Idris, M., Anuar, N., Basri, H. and Mukhlisin, M. 2013b. Effect of 
applying rhizobacteria and fertilizer on the growth ofLudwigia octovalvis for arsenic uptake and accumulation inphytoremediation. Ecological Engineering, 58, 303-313.

20. Rattanawat, C., Rujira, S., Narupot, P., Maleeya, K and Prayad, P. 2011. Effect of soil amendments on growth and metal uptake by Ocimum gratissimum grown in $\mathrm{Cd} / \mathrm{Zn}$-contaminated soil. Water Air Soil Pollution, 214, 383-392.

21. Ball M.C. 1988. Salinity tolerance in the mangroves Aegiceras corniculatum and Avicennia marina. I. Water use in relation to growth, carbon partitioning, and salt balance. Australian Journal of Plant Physiology, 15, 447-464.

22. Khan, M.A., Ungar, I.A. and Showalter, A.M. 2000. Growth, water, and ion relationships of a leaf succulent perennial halophyte, Suaeda fruticosa (L.) Forssk. Journal of Arid Environments, 45. 73-84.

23. Flowers, T.J., Troke, P.F, and Yeo, A.R. 1977. The mechanism of salt tolerance in halophytes. Ann. Rev. Plant Physiology, 28, 89-121.

24. Landis, W.G. and Yu, M.. 1995. Introduction to en- vironmental toxicology, impact of chemicals upon ecological systems, Lewis Publisher, CRCPress, Inc.

25. Chen, Y., Ye, Y. 2014. Effects of Salinity and Nutrient Addition on Mangrove Excoecaria agallocha. PLoS ONE, 9(4): e93337. doi:10.1371/ journal. pone. 0093337

26. Ye, Y., Tam, N.F.Y., Lu, C.Y., Wong, Y.S. 2005. Effects of salinity on germination, seedling growth and physiology of three salt-secreting mangrove species. Aquatic Botany, 83, 193-205.

27. Nandy, P., Das, S., Ghose, M., Spooner-Hart, R. 2007. Effects of salinity on photosynthesis, leaf anatomy, ion accumulation and photosynthetic nitrogen use efficiency in five Indian mangroves. Wetland Ecological Management, 15, 247-357.

28. Popp, M. 1994. Salt resistance in herbaceous halophytes and mangroves. In: Dietmar, H., Luttge, U., Esser, K., Kaderelt, J.W. and Runge, M. (eds.), Progress in Botany. pp. 416-429. Springer Verlag, Berlin.

29. Hegemeyer, J. 1997. Salt. In: Prasad, M.N.V. (ed.), Plant Ecophysiology. pp. 173-206. John Wiley \& Sons, Inc. New York. 